\title{
Population dynamics of the mussel Mytilus edulis: spatial variations in age-class densities of an intertidal estuarine population along environmental gradients
}

\author{
S. McGrorty, J. D. Goss-Custard \\ Institute of Terrestrial Ecology, Furzebrook Research Station, Wareham, Dorset BH20 5AS, United Kingdom
}

\begin{abstract}
This paper tests the hypothesis that the densities of mussels Mytilus edulis in the estuary of the River Exe, SW England, vary along the 2 main directional gradients: the distance upstream and the distance upshore. The densities of different age-classes of mussels on the 12 main mussel beds of the estuary are described. The variation in the density of each age-class was then investigated by multipleregression analysis. In addition to testing for the effect of distance upstream and upshore, the effect of 4 other environmental factors, which could also affect mussel density, were examined. These were: the softness (muddiness) of the substratum, the bed area, the flatness of the substratum surface and the proportion covered by algae. In the presence of these 4 variables, both the distance upstream and the distance upshore (measured as exposure time) had a consistently significant effect on all adult ageclasses. Mussel densities declined gradually upstream. On the other hand their densities peaked at intermediate to high levels of exposure time. A comparison of the standard partial regression coefficients revealed that exposure time had consistently the greatest effect on mussel density across all ageclasses. Exposure time also had the dominant effect on the average age of adult mussels, with mussels living longer on beds that were exposed for only a short time at low water Spat mussels only settled amongst adults. With the effect of adult density taken into account, spat density was lower on soft, muddy beds. The conclusion is that the main environmental gradient along which the population dynamics of mussels in the Exe estuary must be viewed is exposure time.
\end{abstract}

\section{INTRODUCTION}

It has been usual in studies of population dynamics to treat as the population a group of organisms living within a conveniently studied area and then to study as a whole the population processes taking place within it. Of course, this is merely a convenient abstraction because, in reality, population densities and processes vary spatially along environmental gradients that exist at several levels of scale. Because immigration and emigration occur at most levels of scale, population size and density in one area may depend as much on processes taking place in other places as on those in the study area itself. Watkinson's (1985) study of Cakile edentula (Bigel.) Hook provides a good example of population processes varying along environmental gradients that define the species niche. The population dynamics in one place may not be fully understood unless studies are also made on other groups which interact through immigration and emigration with the study population itself (Lomnicki 1978, 1980, Allen \& Barker 1990). This is especially so at levels of scale that are small compared with the mobility range of the organism concerned. As the level of scale considered increases, the dynamics will be less affected by movements and will become increasingly dominated by the interplay between birth and death rates. A quite defensible viewpoint, in fact, is that one is dealing with a 'population' only when studying the level of scale at which movements have only trivial effects and numbers are determined almost entirely by birth and death rates. With organisms that have a great potential for dispersal, such as many marine invertebrates, this would mean studying an enormous geographic area, and this is impractical. On the other hand, the combined properties of many local groups, or the 'metapopulation', will depend not only on the interactions between them (Connell 1985, Roughgarden et al. 1985 , 
Roughgarden \& Iwasa 1986, Hastings \& Wolin 1989, Hughes 1990, Sutherland 1990, Taylor 1990) but also on the processes taking place within each group, such as density-dependent mortality (Hancock 1973, Beukema 1982); self-thinning (Hughes \& Griffiths 1988); density-limited growth (Okamura 1986, Morrisey 1987) and density-dependent emigration (Ambrose 1986). Studies within particular localities therefore have an important role to play, though they need to be considered within a framework of the larger, or meta-population of which they are only a part. The EC COST 647 programme is a rare attempt to describe variations in population processes in selected species throughout their geographic range in western Europe (Lewis et al. 1982, Bowman \& Lewis 1986, Kendall \& Lewis 1986, Lewis 1986).

As field studies of population processes have increased in number and scope, more attention is being given to the role of spatial variations in population dynamics. This has included studies of populations of a species in different places at the same level of scale (Bayne \& Worrall 1980, Griffiths 1981, Bayne et al. 1983, Bushek 1988, Harvey \& Vincent 1989, 1990, Possingham \& Roughgarden 1990, Wilson 1990) and in the same place at different levels of scale (Hassell et al. 1987, Jones et al. 1987, Southwood et al. 1989, Raimondi 1990). The present study was designed to examine the extent to which the understanding of the dynamics of the mussel Mytilus edulis L. population occurring within the study estuary as a whole (McGrorty et al. 1990) would be helped by studies of the individual mussel beds which comprise it. Practical limitations restricted the study to these 2 levels of scale, though studies at finer levels of scale (within beds) and at larger levels of scale (between estuaries) are planned. This paper tests the hypothesis that the densities of mussels vary along the 2 main directional gradients within the estuary; the distance upstream and the distance upshore. But because other factors that could affect mussels might also vary along the same gradients, it was also necessary to take their effect on mussel density into account. Later papers will consider how the dynamics on individual beds vary along the environmental gradient and combine to determine the dynamics of the intertidal mussel population as a whole.

\section{METHODS}

Study area. The work was done on the Exe estuary in southwest England. There were few subtidal mussels and most mussels occurred on 31 intertidal beds. Many beds were small and several disappeared during the study, conducted from September 1976 to September
1983. Most of the adult ( $>1$ yr old) mussels $(91 \%$ ) and spat $(95 \%)$ occurred on just 12 of the beds. The density and age-distribution of the mussels varied considerably between these beds, which were therefore selected for study (Fig. 1). Each one was sampled every September and March. The sampling technique and the method used for measuring and ageing mussels is described in detail in McGrorty et al. (1990). In brief, 600 quadrat samples of 0.04 or $0.02 \mathrm{~m}^{-2}$ in area were collected from the 12 beds according to a stratified random scheme. Mussels were counted, measured to the nearest mm and aged by counting external 'growth' rings. Bed areas were calculated from maps based on a series of parallel lines measured across each bed each time it was sampled.

Environmental variables. The reasons for selecting the variables, the methods used to measure them and their 5-letter abbreviated names are as follows.

Distance upstream in the estuary of the River Exe. (DUPEX): A bed's distance from the sea could affect the supply of plantigrade larvae available to settle on it since many may choose to settle on the first bed they encounter and the distance a free-floating plantigrade is carried up the estuary will depend on the time during the flood tide when it enters the estuary. The distance up the estuary will also affect the salinity of the water column, and so the growth and survival rates of the mussels (Bayne 1965, Remane \& Schlieper 1971, Seed 1976, Essink \& Bos 1985). Salinity was not measured, but there appears to be little decline in salinity at high water, when the mussel beds are covered, until above the upstream limit of mussels at Lympstone (Murray 1980). Distance up the estuary may also affect the

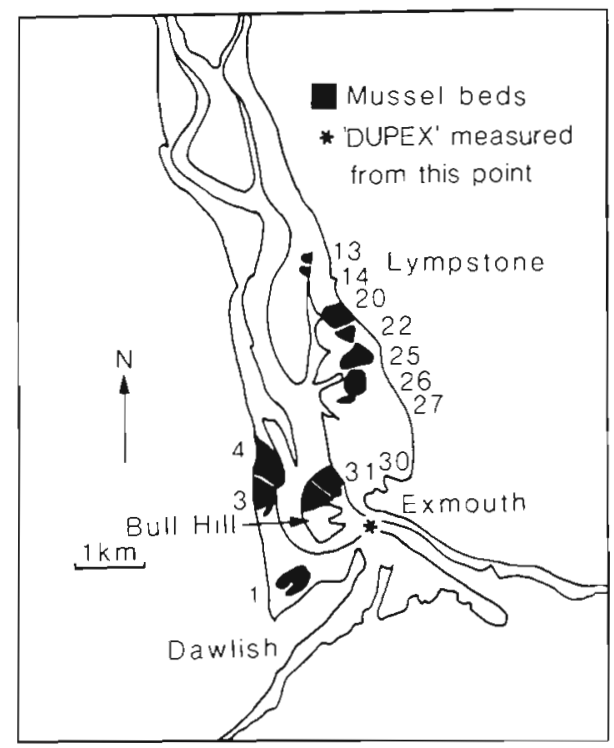

Fig. 1. The Exe estuary, SW England, showing the 12 mussel beds studied 
supply of plankton food (Smaal et al. 1986, Smaal \& von Stralan 1990) as it is progressively depleted by suspension feeders in the mud and sand flats (Peterson \& Black 1987, Vincent et al. 1989) and by the mussel beds themselves (Wildish \& Kristmanson 1984, Frechette \& Bourget $1985 \mathrm{a}, \mathrm{b})$. DUPEX was measured as the distance from the mid-point of the bed to the mid-point of the estuary at the mouth between Dawlish Warren and Exmouth (Fig. 1).

Distance upshore, measured as the amount of time the bed is exposed at low tide (EXPOS): This would affect the time available for spat to settle over the hightide period, the time available each tidal cycle for mussels to feed, the relative proportion of the time they are vulnerable to marine and terrestrial predators and the proportion of the time they are exposed to adverse climatic conditions, such as high or low temperatures and heavy rainfall (Lewis 1964, Seed 1976, Suchanek 1985, Menge \& Farrell 1989). The times the first and last parts of a bed were exposed and covered on the receding and advancing tides respectively were recorded. The mid-point between the first and last exposure and between the first and last covering were then calculated. The time between these 2 mid-points, over the low water period, was then expressed as a proportion of the time between the first and the second high water. The measurements were made simultaneously on all beds on a typical spring and a typical neap tide. The average of these 2 values was used as the measure of exposure time.

Softness of the substrata (SOFTY): On rocky shores and in large exposed embayments, mussel spat settle on firm, clean substrata (Dare 1976, Seed 1976). In sheltered estuaries with soft sediments, they settle predominantly on existing beds, amongst the byssus threads of adults (McGrorty et al. 1990). Soft, muddy beds are likely therefore to deter settlement, partly because few hard and clean surfaces occur there and partly because many byssus threads may be buried in mud. In addition, established mussels cease filter-feeding when high concentrations of sediment occur in the water column (Widdows et al. 1979). The softness of the substratum was measured on each bed in April 1978 by dropping a steel rod from a fixed height and measuring the distance it penetrated the sediment between mussels. On each bed, 25 measurements were made at random, and the mean value calculated.

Area of the bed (BAREA): Large beds may have a higher chance than small ones of spat being carried over them by the tide and, if they are gregarious (Seed 1976), spat may be attracted to, or more likely to settle on, large concentrations of mussels. Bed area was measured as described in McGrorty et al. (1990).

Unevenness of the substratum surface (FLATY). Since the attachment of mussel larvae on algal fila- ments and on byssus threads is enhanced by water agitation (Eyster \& Pechenik 1987), more spat may settle on beds with an uneven surface where water turbulence may be high. Higher rates of turbulence might also allow a greater proportion of the water column to be filtered by the mussels, thus increasing their food supply. The evenness, or flatness, of each bed was measured optically. An orange ball, $30 \mathrm{~cm}$ in diameter, was pulled over the surface of the bed along a series of lines, each terminating at the edge of the bed. The location the line began and its direction were chosen at random. An observer, standing at the start of the line, watched the ball as it was pulled away and recorded the proportion of the line over which the ball could be seen through a mirror placed $20 \mathrm{~cm}$ above the substratum. The mean of 20 such measurements was used as the estimate of bed flatness, high values indicating that the bed was flat.

Proportion covered by algae (ALGAE): In gales, the whiplash movement of surface algae (Lewis 1964), and the increased drag and lift if they are attached to each other (Witman \& Suchanek 1984), can dislodge epibenthic species, including mussels. On the other hand, algal cover may provide a sheltered, damp habitat, which reduces dessication stress and so aid survival of newly settled larvae (Dayton 1971, Baxter \& Jones 1989). On each bed, 25 randomly placed $50 \times 50 \mathrm{~cm}$ quadrats were taken and the proportion of each that was covered in algae gauged by eye. The mean value measured the proportion of the bed covered by algae.

\section{RESULTS}

\section{Patterns of mussel density and change in density with} age within the estuary

The densities of each age class of mussel, and the pattern of change in density with age, varied between the different beds. It is convenient to first describe the patterns of spatial variation in both characteristics by reference to the position of a bed along just one of the gradients within the estuary, the distance upstream. This is done in Fig. 2 which shows the mean densities recorded over all the 15 September and March sampling occasions between 1976 and 1983. The possible effect of environmental factors other than DUPEX on the patterns observed are investigated later by multiple-regression analysis.

\section{First-year mussels}

These were the recently-settled plantigrade larvae and spat that settled on a bed between one March and 


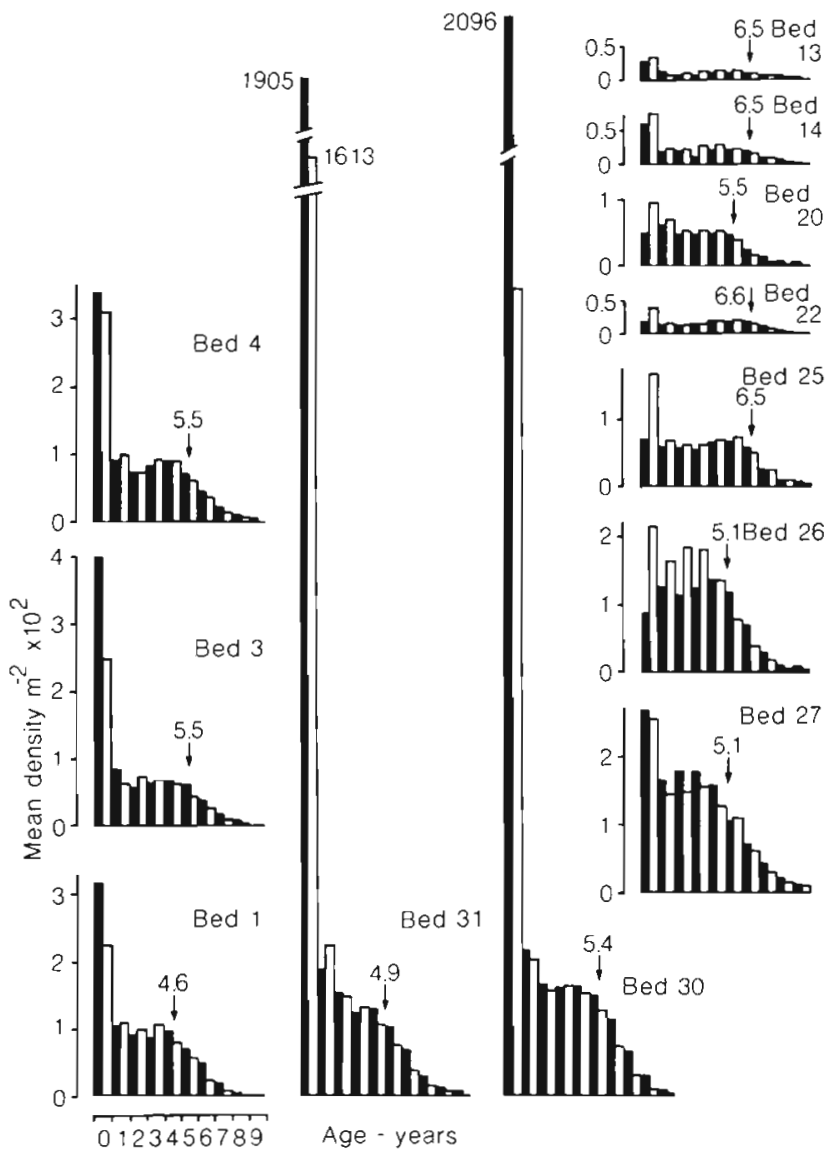

Fig. 2. Mytilus edulis. Mean densities on each bed from 1976 to 1983 of each age class of mussels in March (black bars) and September (open bars). Histograms are placed approximately according to the positions of the beds within the estuary. Arrows indicate the age after which there was a marked increase in mortality

the next (referred to collectively as spat). The most noticeable aspect of their distribution was the huge preponderance of spat, in both March and September, on the 2 large beds ( 30 and 31 ) near to the mouth of the estuary (Fig. 2). On the east side, where beds occurred well up into the estuary, spat density declined gradually with distance up the estuary. Beds only occurred in the lower reaches on the west side but spat densities in March were higher than on beds at the same point on the east side.

This difference between the 2 sides of the estuary was much smaller by September because there was a consistent change in densities over the summer that was related to distance up the estuary. On average, spat densities decreased between March and September in the downstream beds on both sides of the estuary (Beds 1, 3, 4, 27, 30, 31), whereas they increased on the upstream beds (Fig. 3a). Spat densities decreased between March and September in more years than they increased on these downstream beds, while the reverse was the case in the upstream beds (Fig. 3b). In other words, the establishment of spat on the downstream beds occurred predominantly in spring whereas, on the upstream beds, it mainly occurred later in the summer. Since, on average, $87 \%$ of spat within the whole estuary established themselves on the downstream beds ( $71 \%$ on just 2 beds, $30 \& 31$ ), spat settlement overall was spring-dominated.

The density of firstyear mussels on most beds decreased sharply between September and the following March (Fig. 2). A very powerful density-dependent mortality factor operated over the winter on this ageclass (McGrorty et al. 1990) so that, in general, densities decreased most on beds where, in September, spat densities had been highest. Consequently, by the time mussels reached 1 yr of age in March, the variation in density between beds was much less than had been the case during the first year (Fig. 2).

\section{Adult mussels}

From the beginning of their second year in March, densities decreased with age on all beds. However, the pattern of change varied considerably between them (Fig. 2). Densities changed very little on most beds between March in Year 2 and September in Year 4. In fact, significant trends against date occurred only on 3 beds: a decrease in density on Bed $31(r=-0.92$, $\mathrm{p}<0.01)$ and increases on Beds $22(\mathrm{r}=0.85, \mathrm{p}<0.01)$ and 25 ( $\mathrm{r}=0.75, \mathrm{p}<0.05)$. The change was within $\pm 25 \%$ in 10 of the 12 beds. Nonetheless, when the

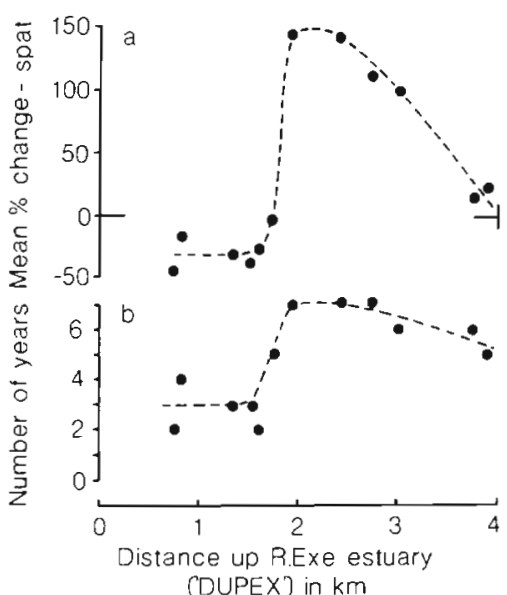

Fig. 3. Mytilus edulis. Change in the density of spat mussels between March and September on each bed, ordered according to their position up the estuary. (a) Mean over-summer percentage change during the 7 yr (b) Numbers of years when beds gained spat over the summer Lines were fitted by eye 


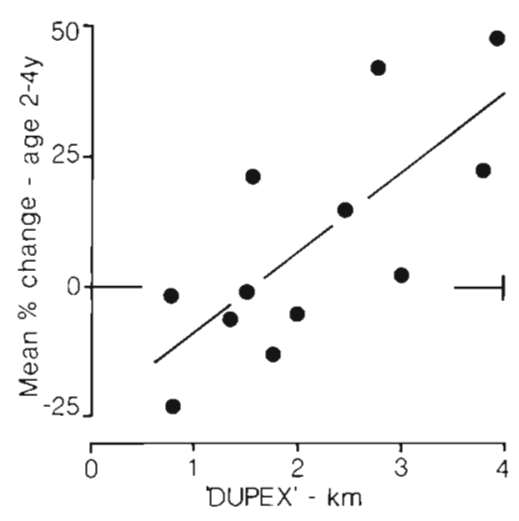

Fig. 4. Mytilus edulis. Mean percentage change in the densities of mussels between 2 and 4 yr old on each bed. Beds are ordered according to their position up the estuary. The overall trend is described by the regression equation: Mean \% change $(2-4$ yr $)=15.35$ DUPEX $(\mathrm{km})-24.18 ; \mathrm{r}=0.74$, $\mathrm{p}<0.01$

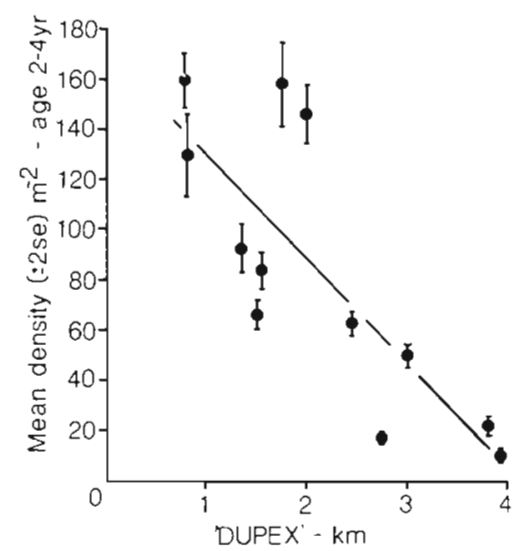

Fig. 5. Mytilus edulis. Mean density ( \pm 2 standard errors) of the 2- to 4-yr-old mussels on each bed. Beds are ordered according to their position up the estuary. The decline in density with distance up the estuary is described by the regression equation: Adult density $(2-4 \mathrm{yr}) \mathrm{m}^{-2}=172.45-$ 41.68 DUPEX $(\mathrm{km}) ; \mathrm{r}=-0.80, \mathrm{p}<0.01$

change on each bed over the period was expressed as a percentage, there was a significant trend across beds $(\mathrm{r}=0.74, \mathrm{p}<0.01)$ for the downstream beds to lose mussels and for the upstream beds to gain them (Fig. 4). Even so, compared with earlier ( 0 to 1 yr) and later ( 5 to 9 yr) periods, numbers changed relatively little on most beds between Years 2 and 4 . Averaged over this age range, density decreased upstream (Fig. 5).

After this period, the densities of adults on most beds began to decrease sharply, but at an age which varied between beds (Fig. 2). The age at which this occurred was first estimated approximately by eye. It was then determined more precisely as the point of intersection of 2 straight lines drawn through the cumulative density curve on either side of the initial estimate. The estimates of 3 observers agreed closely and the mean age at which the decrease started varied between 4.6 (Bed 1) and 6.6 yr (Bed 22).

The mean age of all adults ( $>1 \mathrm{yr}$ old) varied between 3.06 (Bed 31) and 4.22 yr (Bed 13) and also increased up the estuary (Fig. 2). Like the densities of all other age classes, the densities of old mussels ( 5 or more years old) decreased upstream (Fig. 6a), but nonetheless formed a higher proportion of the adult population as a whole (Fig. 6b). In other words, mussels on the upstream beds occurred at lower overall densities but survived longer and thus had a higher average age.

\section{Correlates of mussel density and change in density with age within the estuary}

This section tests the hypothesis that these large differences between beds in the densities of the various age classes were related to the 2 directional gradients, the distance upstream and distance upshore, or exposure time. A multiple-regression analysis was used so that their effect could be estimated in the presence of the other 4 variables measured.
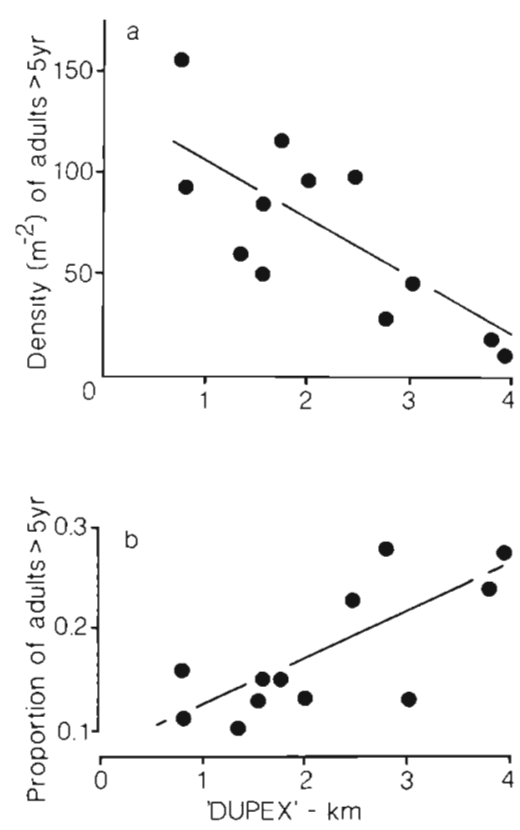

Fig. 6. Mytilus edulis. (a) Mean density of older ( $>5$ yr) adult mussels on each bed over the $7 \mathrm{yr}$ The up-estuary decline in density is described by the regression equation: Adult density $(>5 \mathrm{yr}) \mathrm{m}^{-2}=131.36-27.43 \operatorname{DUPEX}(\mathrm{km}) ; \mathrm{r}=-0.68, \mathrm{p}<0.01$. (b) Proportion of older adult mussels on each bed. The upestuary increase in the proportion of older mussels is described by the regression equation: Proportion of adults $>5 \mathrm{yr}=0.044$ DUPEX $(\mathrm{km})+0.079 ; \mathrm{r}=0.74, \mathrm{p}<0.01$ 
Patterns of association amongst the environmental variables

The values of each variable for each bed are shown in Table 1.

Inter-correlations between environmental variables occurred between 4 of the variables (Table 2). Upstream beds tended to be exposed for a shorter time $(\mathrm{r}=0.65, \mathrm{p}<0.05)$ and to have softer substrata $(\mathrm{r}=$ $0.65, \mathrm{p}<0.05$ ). It would therefore be expected that, in general, beds exposed for a short time would have had softer substrata but, superficially, this was not so ( $\mathrm{r}=$ -0.07 , ns). The reason is that the softness of the substratum varied with both distance upstream and exposure time. When partial correlation coefficients were calculated, the substratum became softer both upstream ( $\mathrm{r}=0.79, \mathrm{p}<0.01)$ and upshore as the exposure time increased $(r=0.79, p<0.01)$. The softness of the substratum therefore increased along both of the directional gradients that were aligned at right-angles to each other. The upstream beds also tended to be flatter than the downstream beds ( $\mathrm{r}=0.77, \mathrm{p}<0.01$ ). Neither bed area or algal cover was intercorrelated closely with any of the other variables or with each other. In the multiple-regression analysis, the logarithms of SOFTY and ALGAE were used as their

Table 1. Values of the environmental variables measured on each mussel bed. See 'Methods' for full definitions of variables

\begin{tabular}{|c|c|c|c|c|c|c|}
\hline Bed & $\begin{array}{c}\text { DUPEX } \\
(\mathrm{km})\end{array}$ & $\begin{array}{c}\text { EXPOS } \\
(\%)\end{array}$ & $\begin{array}{c}\text { SOFTY } \\
(\mathrm{cm})\end{array}$ & $\begin{array}{c}\text { BAREA } \\
\text { (ha) }\end{array}$ & $\begin{array}{c}\text { FLATY } \\
(\%)\end{array}$ & $\begin{array}{c}\text { ALGAE } \\
(\%)\end{array}$ \\
\hline 1 & 1.351 & 45.1 & 15.8 & 5.56 & 68.8 & 26.6 \\
\hline 3 & 1.522 & 31.8 & 7.5 & 4.42 & 97.0 & 26.2 \\
\hline 4 & 1.558 & 29.1 & 7.6 & 6.15 & 51.5 & 30.4 \\
\hline 13 & 3.929 & 18.6 & 13.2 & 1.52 & 100.0 & 24.2 \\
\hline 14 & 3.788 & 22.3 & 14.7 & 2.04 & 91.8 & 22.6 \\
\hline 20 & 3.009 & 28.6 & 16.2 & 9.36 & 85.3 & 41.4 \\
\hline 22 & 2.761 & 17.2 & 17.4 & 3.86 & 100.0 & 18.0 \\
\hline 25 & 2.443 & 28.3 & 16.6 & 8.08 & 85.4 & 15.2 \\
\hline 26 & 1.982 & 36.1 & 15.2 & 6.47 & 65.2 & 2.8 \\
\hline 27 & 1.735 & 39.5 & 14.2 & 1.26 & 45.2 & 33.6 \\
\hline 30 & 0.779 & 28.9 & 3.9 & 7.46 & 39.3 & 0.4 \\
\hline 31 & 0.814 & 32.1 & 3.8 & 7.69 & 25.3 & 0.4 \\
\hline
\end{tabular}

Table 2. A simple (Pearson) correlation (r) matrix amongst all the environmental variables

\begin{tabular}{|lrrrrr|}
\hline & DUPEX & EXPOS & SOFTY & BAREA & FLATY \\
\hline EXPOS & -0.651 & & & & \\
SOFTY & 0.647 & -0.070 & & & \\
BAREA & -0.427 & 0.204 & -0.216 & & \\
FLATY & 0.774 & -0.527 & 0.621 & -0.313 & \\
ALGAE & 0.404 & 0.036 & 0.427 & -0.270 & 0.413 \\
\hline
\end{tabular}

effect was thought likely to decrease beyond low values. The EXPOS and its square were used to allow for non-linear effects. The logarithms of mussel densities were used to equalise the variance. The data used were the density estimates from the 8 September surveys of each of the 12 beds, giving a total sample size of 96 .

\section{Densities of adult mussels}

The results of the regression analyses on the densities of adult mussels are summarised in Table 3 . The first part (A) shows the simple $R^{2}$ between each variable and the density of each age-class of mussel. The second part (B) shows the significant variables chosen by step-down multiple-regression analysis. Adult density was defined in 3 ways: as the mean densities of all adult mussels from 1 to $9 \mathrm{yr}$ old ('YR1-9'), as the mean densities of young (2 to $4 \mathrm{yr}_{\mathrm{old}}$ ' 'YR2-4') and as the mean density of old ( 6 to 9 yr old; 'YR6-9') mussels.

Individually, all the associations shown in Table $3 \mathrm{~A}$ were statistically significant; with a sample size of 96 , an $R^{2}$ of just 0.04 is significant at the $5 \%$ level. But as Table 3B shows, bed area and algal cover sometimes
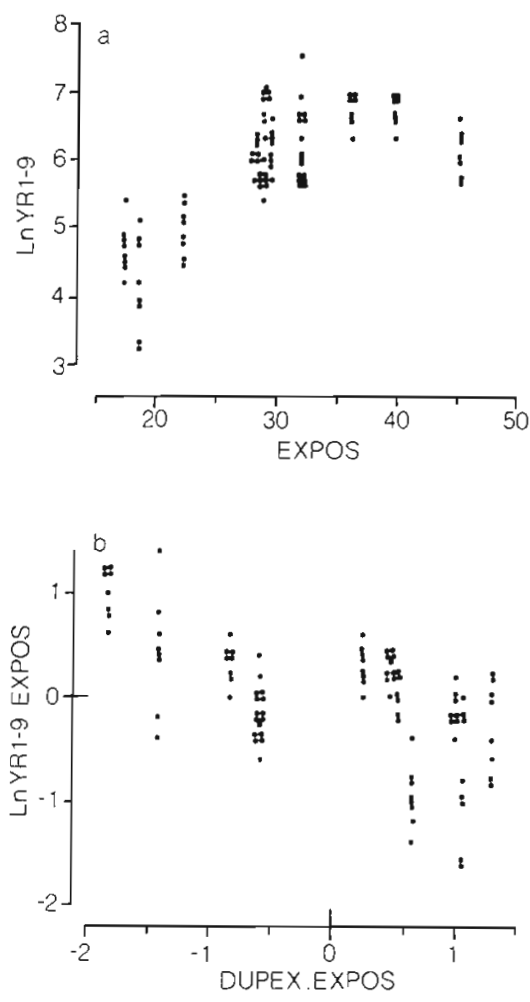

Fig. 7 Mytilus edulis, (a) Relationship between density of adult mussels and exposure time. Regression equation: In YR $1-9=0.40$ EXPOS -0.0053 EXPOS $^{2}-1.08 ; R^{2}=71.3 \%$. (b) Effect of distance up the Exe estuary on adult density with the effect of exposure time taken into account. Regression. equation: In YR1-9. EXPOS $=0.0010-0.36$ DUPEX. EXPOS;

$$
r=-0.60, p<0.001
$$


Table 3A. Environmental correlates of various measures of the density of adult mussels as defined in the text. Values are $\mathrm{R}^{2}-$ the proportion of the variance in the dependent variable explained by each independent variable on its own

\begin{tabular}{|lccccccc|}
\hline $\begin{array}{l}\text { Dependent } \\
\text { variable }\end{array}$ & DUPEX & EXPOS & $\begin{array}{c}\text { Quadratic in } \\
\text { EXPOS }\end{array}$ & ln SOFTY & BAREA & FLATY & In ALGAE \\
\hline In YR1-9 & 0.613 & 0.511 & 0.713 & 0.162 & 0.209 & 0.557 & 0.208 \\
ln YR2-4 & 0.605 & 0.558 & 0.745 & 0.148 & 0.201 & 0.527 & 0.186 \\
In YR6-9 & 0.275 & 0.124 & 0.320 & 0.090 & 0.078 & 0.280 \\
\hline
\end{tabular}

Table 3B. Significant environmental correlates of the density of adult mussels, and the proportion of the variance in the dependent variable $\left(R^{2}\right)$ explained by them in combination, when all 6 independent variables were entered in a step-down multiple regression analysis. b: regression coefficient, SE: standard error of b; SPRC: standard partial regression coefficient (b $\times$ SD); : probability: ' significance at $p<5 \%,{ }^{\cdots} p<1 \%, \cdots p<0.1 \%$; ns: not significant

\begin{tabular}{|c|c|c|c|c|c|c|c|c|c|c|}
\hline $\begin{array}{l}\text { Dependent } \\
\text { variable }\end{array}$ & & DUPEX & EXPOS & EXPOS $^{2}$ & ln SOFTY & BAREA & FLATY & ln ALGAE & Intercept & $\mathrm{R}^{2}$ \\
\hline In YR1-9 & $\begin{array}{l}\mathrm{b} \\
\pm \mathrm{SE} \\
\mathrm{SPRC} \\
\mathrm{p}\end{array}$ & $\begin{array}{c}-0.4285 \\
0.0855 \\
-0.4358 \\
\ldots\end{array}$ & $\begin{array}{c}0.3031 \\
0.0350 \\
2.3645 \\
\ldots\end{array}$ & $\begin{array}{c}-0.00452 \\
0.00056 \\
-2.1728 \\
\ldots\end{array}$ & $\begin{array}{c}0.7651 \\
0.1475 \\
0.4114 \\
\cdots\end{array}$ & ns & $\begin{array}{c}-0.00999 \\
0.00272 \\
-0.2491 \\
\ldots\end{array}$ & $\begin{array}{r}-0.0978 \\
0.0358 \\
-0.0606 \\
. .\end{array}$ & 1.1480 & 0.853 \\
\hline ln YR2-4 & $\begin{array}{l}\mathrm{b} \\
\pm \mathrm{SE} \\
\mathrm{SPRC} \\
\mathrm{p}\end{array}$ & $\begin{array}{r}-0.3942 \\
0.0922 \\
-0.4009 \\
\ldots\end{array}$ & $\begin{array}{c}0.3289 \\
0.0378 \\
2.5657 \\
\ldots\end{array}$ & $\begin{array}{c}-0.00470 \\
0.00061 \\
-2.2593 \\
\cdots\end{array}$ & $\begin{array}{c}0.6913 \\
0.1590 \\
0.3717 \\
\ldots\end{array}$ & ns & $\begin{array}{c}-0.00819 \\
0.00293 \\
-0.2042 \\
\cdots\end{array}$ & $\begin{array}{r}-0.1046 \\
0.0386 \\
-0.2584 \\
\ldots\end{array}$ & -0.1090 & 0.851 \\
\hline ln YR6-9 & $\begin{array}{l}\mathrm{b} \\
\pm \mathrm{SE} \\
\mathrm{SPRC} \\
\mathrm{p}\end{array}$ & $\begin{array}{r}-0.7456 \\
0.1637 \\
-0.7583 \\
\cdots\end{array}$ & $\begin{array}{c}0.3560 \\
0.0713 \\
2.7772 \\
\ldots\end{array}$ & $\begin{array}{c}-0.00649 \\
0.00118 \\
-3.1197 \\
\ldots\end{array}$ & $\begin{array}{l}1.2360 \\
0.2649 \\
0.6646 \\
\ldots .\end{array}$ & $\begin{array}{c}-0.00758 \\
0.00317 \\
-0.1978 \\
.\end{array}$ & $\begin{array}{c}-0.0144 \\
0.0044 \\
-0.3590 \\
\cdots\end{array}$ & ns & -0.6220 & 0.517 \\
\hline
\end{tabular}

lost their significance when the effects of the other variables were taken into account. The high standard partial regression coefficients for EXPOS and EXPOS ${ }^{2}$ show that exposure time had the largest association. with variations in mussel density. The variable DUPEX had a much smaller effect but, nonetheless, the results are consistent with the main hypothesis being tested; both distance upstream and exposure time retained their significance at a high level in the presence of the other significant variables.

The relationship between adult density and exposure time was in all cases non-linear because both EXPOS and $\operatorname{EXPOS}^{2}$ were highly significant. The relationship is illustrated in Fig. 7 a for adults of all ages. On its own, the quadratic expression of exposure time explained $71.3 \%$ of the variation in adult density (Table $3 \mathrm{~A}$ ). Adult density increased with exposure time over twothirds of the range encountered, but decreased at higher values; they were highest within the range of 30 to $40 \%$ exposure time. Fig. $7 \mathrm{~b}$ shows the relationship with distance upstream, with the effect of exposure time held constant. There is no evidence of non-linearity in these data.

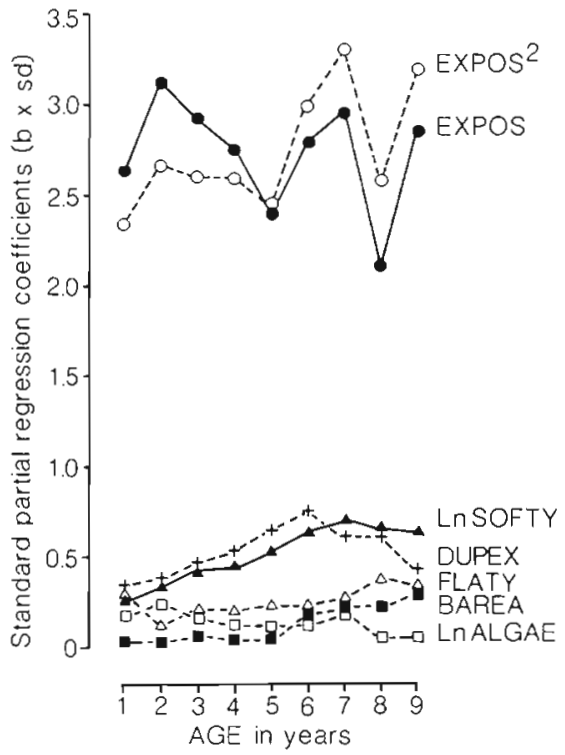

Fig. 8. Mytilus edulis. Correlates of adult mussel density in each age-class. The standard partial regression coefficients for each of the 6 variables considered are shown. For ease of comparison variables with positive $(-)$ and negative (---) values are plotted together 
The results were similar irrespective of how adult density was defined, and YR 1-9 is used here simply to summarise and illustrate the trends revealed by the analysis. An ANOVA revealed that $87.2 \%$ of the variation in mussel density on the 12 beds over the $8 \mathrm{Sep}$ tember surveys was due to differences between beds, with only $1.2 \%$ being attributed to differences between years. Clearly the multiple-regression analysis was primarily concerned with explaining spatial variations in mussel density.

The relative importance of the 6 variables in accounting for the spatial variations in the densities of each age-class are graphed in Fig. 8. This shows the standard partial regression coefficients between the density of each age-class and the 6 environmental variables. Mussel density was most affected by both EXPOS and EXPOS $^{2}$ over the entire age range. Though their effect was small in comparison, both SOFTY and DUPEX had an increasing effect with age. It is surprising that the densities were higher where the substrata were softer.
However this may have been an artefact because densities were somewhat lower on the flatter beds, and these were also generally the softer ones. The other variables had very little effect. The results are consistent with the hypothesis that both the distance upstream and upshore had a consistent effect on the densities of all adult age-classes. Of all the variables considered, the distance upshore, EXPOS, had by far the greatest effect.

\section{Longevity}

Table 4 summarises the environmental correlates of various measures of the ages to which mussels lived on the various mussel beds. Age was defined in 4 ways: the proportion of adults that were $6 \mathrm{yr}$ and older ('PROPOLD'); the mean age of adult mussels ('MEAN$\left.A G E^{\prime}\right)$; the age above which only $5 \%$ of mussels occurred ('OLDEST $5 \%$ ') and, finally, the age at which the

Table 4A. Environmental correlates of various measures of the age of adult mussels as defined in the text. Values are $\mathrm{R}^{2}-$ the proportion of the variance in the dependent variable explained by each independent variable on its own

\begin{tabular}{|lccccccc}
\hline $\begin{array}{l}\text { Dependent } \\
\text { variable }\end{array}$ & DUPEX & EXPOS & $\begin{array}{c}\text { Quadratic in } \\
\text { EXPOS }\end{array}$ & ln SOFTY & BAREA & FLATY & In ALGAE \\
\hline PROPOLD & 0.207 & 0.291 & 0.313 & 0.065 & 0.110 & 0.150 & 0.055 \\
MEANAGE & 0.185 & 0.203 & 0.229 & 0.088 & 0.088 & 0.169 & 0.089 \\
OLDEST 5 \% & 0.137 & 0.224 & 0.231 & 0.043 & 0.084 & 0.089 & 0.040 \\
PLATEND & 0.119 & 0.112 & 0.112 & 0.042 & 0.039 & 0.073 & 0.067 \\
\hline
\end{tabular}

Table 4B. Significant environmental correlates of the age of adult mussels, and the proportion of the variance in the dependent variable $\left(R^{2}\right)$ explained by them in combination, when all 6 independent variables were entered in a step-down multiple regression analysis. $b$ : regression coefficient; SE: standard error of $b$; SPRC: standard partial regression coefficient $(b \times S D)$; $p$ : probability; ${ }^{\cdot}$ significance at $p<5 \%, \cdots p<1 \%, \cdots p<0.1 \%$; ns: not significant

\begin{tabular}{|c|c|c|c|c|c|c|c|c|c|c|}
\hline $\begin{array}{l}\text { Dependent } \\
\text { variable }\end{array}$ & & DUPEX & EXPOS & EXPOS $^{2}$ & ln SOFTY & BAREA & FLATY & In ALGAE & Intercept & $\mathrm{R}^{2}$ \\
\hline PROPOLD & $\begin{array}{l}\mathrm{b} \\
\pm \mathrm{SE} \\
\mathrm{SPRC} \\
\mathrm{p}\end{array}$ & $\begin{array}{r}-0.0345 \\
0.0168 \\
-0.0351 \\
.\end{array}$ & ns & $\begin{array}{c}-0.000125 \\
0.000025 \\
-0.0600 \\
\cdots\end{array}$ & $\begin{array}{l}0.0715 \\
0.0240 \\
0.0384 \\
\ldots\end{array}$ & $\begin{array}{c}-0.000886 \\
0.000287 \\
-0.0231 \\
\ldots\end{array}$ & ns & ns & 0.2115 & 0.398 \\
\hline MEANAGE & $\begin{array}{l}\mathrm{b} \\
\pm S E \\
\text { SPRC } \\
p\end{array}$ & ns & ns & $\begin{array}{c}-0.000585 \\
0.000122 \\
-0.2814 \\
\cdots\end{array}$ & $\begin{array}{c}0.3740 \\
0.1088 \\
0.2011 \\
\cdots\end{array}$ & ns & ns & ns & 3.1535 & 0.270 \\
\hline OLDEST $5 \%$ & $\begin{array}{l}b \\
\pm S E \\
S P R C \\
p\end{array}$ & $\begin{array}{r}-0.4125 \\
0.1711 \\
-0.4195 \\
.\end{array}$ & ns & $\begin{array}{c}-0.00121 \\
0.00026 \\
-0.5816 \\
\cdots\end{array}$ & $\begin{array}{l}0.7245 \\
0.2429 \\
0.3896 \\
\cdots\end{array}$ & $\begin{array}{c}-0.00839 \\
0.00291 \\
-0.2188 \\
. .\end{array}$ & ns & ns & 7.5229 & 0.328 \\
\hline PLATEND & $\begin{array}{l}b \\
\pm S E \\
\text { SPRC } \\
p\end{array}$ & ns & ns & $\begin{array}{c}-0.000663 \\
0.000191 \\
-0.3186 \\
\cdots\end{array}$ & ns & ns & ns & $\begin{array}{c}0.1538 \\
0.0571 \\
0.2480 \\
\cdots\end{array}$ & 5.8334 & 0.173 \\
\hline
\end{tabular}


adult densities began to decrease sharply ('PLATEND'). Once again, most of the simple values of $\mathrm{R}^{2}$ were significant (Table $4 \mathrm{~A}$ ). The multiple-regression analysis selected a much reduced suite of variables. In all cases, the most consistent and highly significant correlate with the largest standard partial regression coefficients was exposure time (EXPOS $\left.{ }^{2}\right)$. The relationship was negative suggesting that the mussels lived for longer on beds at the lower levels of the shore. None of the other variables had as consistent an effect, with such high levels of significance, across all definitions of age.

The variation in the proportion of the adults that were 6 yr and older is used to illustrate the trends found by the multiple-regression analysis. An ANOVA revealed that $47.9 \%$ of the variation in PROPOLD was due to differences between beds, with only $9.3 \%$ being due to differences between years. Therefore the regression was dealing primarily with spatial variations in adult mussel age. Of the variables considered, the quadratic in exposure time on its own (Table 4A) accounted for $31 \%$ of the variation in PROPOLD which is $78 \%$ of the variation explained by the regression equation as a whole (Table $4 \mathrm{~B}$ ). Its relationship with EXPOS $^{2}$, which was selected by the multiple-regression analysis, is shown in Fig. 9.

\section{First-year mussels}

Spat mussels only settled on the Exe amongst adults, so the density of first-year mussels was closely correlated with adult density (Fig. 10a). Accordingly, adult density ( 1 to 9 yr olds combined; 'YR 1-9') was included in the suite of variables whose possible effects on the density of first-year mussels ('YRO') were examined. The only variable that had a significant effect additional to that of adult density was the softness of the substratum. The equation was:

$$
\begin{gathered}
\ln \mathrm{YRO}=2.80+0.851 \ln \mathrm{YR} 1-9-1.13 \mathrm{SOFTY} \\
\mathrm{R}^{2}=76.3 \%
\end{gathered}
$$

In other words, with the effect of adult mussels taken into account, spat densities were lower where the substratum was soft and muddy (Fig. 10b).

\section{DISCUSSION}

There were marked spatial variations in the densities of the various age-classes of mussels over the estuary. By far the highest densities of spat mussels in March, during the main settlement period, occurred on the 2 largest beds at the mouth of the estuary. Spat densities declined sharply upstream. But the pattern changed somewhat by September because, on average, the densities of spat on the downstream beds decreased over the summer while those on the upstream beds continued to increase.

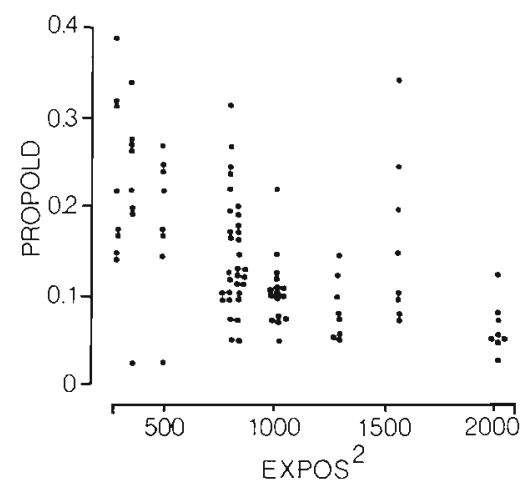

Fig. 9. Mytilus edulis. Relationship between proportion of old mussels ( $>5$ yr old) and exposure time. Regression equation: PROPOLD $=0.223-0.000085$ EXPOS $^{2} ; \mathrm{r}=-0.51, \mathrm{p}<0.001$
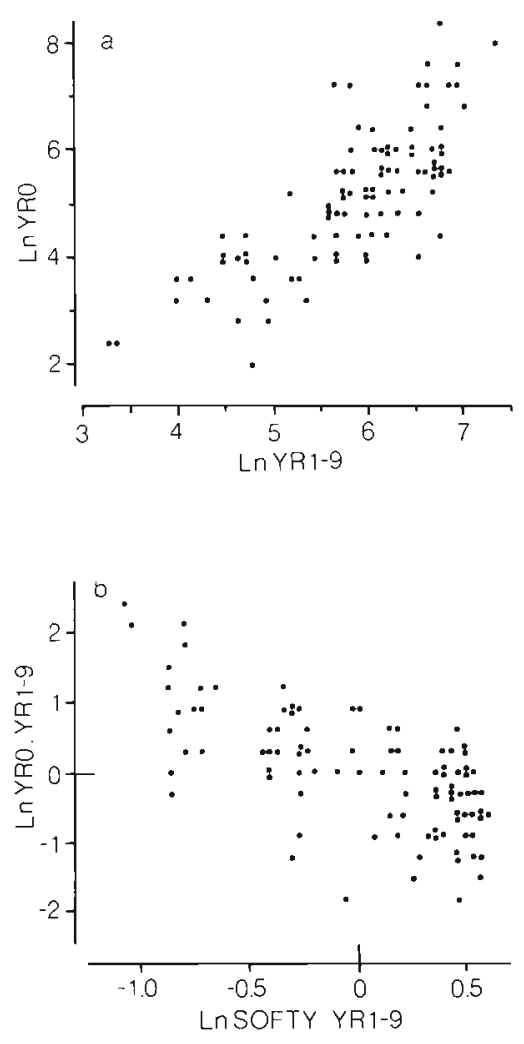

Fig. 10. Mytilus edulis. (a) Relationship between density of spat mussels (ln YR0) and density of adults (ln YR1-9). Regression equation: $\ln$ YR0 $=1.13 \ln$ YR1-9 $-1.55 ; \mathrm{r}=0.76, \mathrm{p}$ $<0.001$. (b) Effect of substratum softness on density of spat mussels with the effect of density of adults taken into account. The relationship is described by the regression equation: In YR0. $\ln Y R 1-9=0.00-1.13 \ln$ SOFTY. In YR1-9; $r=-0.67, p$ $<0.001$ 
There are 2 explanations for the tendency for spat to occupy the 2 large downstream beds first in spring, neither of which has yet been tested. One is that the supply of spat, perhaps for hydrographic reasons (Scheltema 1971), was lower in the higher reaches of the river so that recruitment rates were low. On this hypothesis, the initial difference between the upstream and downstream beds in spat densities would be diminished by the continuing low-level supply over the summer period. The lower supply of spat upstream could itself be due either to an inability to penetrate far up the estuary or to their being removed from the water column when they pass over the downstream beds. During the period of maximum tidal flow (from ca $40 \%$ flood), the main current passes directly over Beds 30 and 31, which are situated just inside the mouth of the estuary. If a large proportion of the spat choose to settle in the first suitable place they encounter, the density of spat in the water could be much reduced before reaching any of the other beds upstream (Jackson 1986).

The second possibility is that the availability of settling space was limited to different degrees on the various beds. Spat only settle amongst clean adult byssus threads on the Exe (McGrorty et al, 1990). On this explanation, the 2 large, gravel-based beds at the mouth of the estuary would be settled most by spat in spring because a large proportion of the byssus threads of the numerous adults there would be free from mud. The upstream beds were much more muddy than Beds 30 and 31, and the analysis revealed a strong aversion by spat mussels for soft substrata. On this hypothesis, the increase in spat density between March and September on the upstream beds would have been due to an increase in the settlement space available during the intervening months. For example, gales might have stripped mud from within clumps of adults, allowing the spat to establish themselves before further deposition occurred. But whatever the explanation, the huge densities of spat settling on the 2 large downstream beds in the spring dominated the pattern of settlement over the estuary. As a result, spat settlement as a whole occurred mainly in spring.

The mortality occurring over the first winter was strongly density-dependent (McGrorty et al. 1990) and reduced the initial variation in spat density between the beds. Compared with earlier and later periods in the mussels life, the density changed rather little on most beds over the next 2 or 3 yr. However, there was a significant tendency for upstream beds to gain 2- to 3yr-old mussels and for downstream beds to lose them. This strongly implies that some upstream migration of adult mussels was taking place, probably by 'rafting', which was observed on a number of occasions, driven by the prevailing southwesterly gales.

In addition to this, the age at which adult densities started rapidly to decline was higher upstream than on the downstream beds. This may reflect a lower mortality rate of the older individuals on the upstream beds, but may also have resulted from the continuing arrival of immigrants from the downstream beds. But as a consequence of this, the proportion of the adults that were relatively old ( $>5$ yr old) was also higher on the upstream beds, even though their absolute densities were lower than further downstream. As a result, the mid-point of the population of each age class moved gradually up the estuary as the mussels aged: it occurred on Bed 31 for 0-yr mussels but, for 9-yr and older mussels, it occurred on Bed 26.

The multiple regression analysis confirmed that the distance of a bed up the estuary had a significant effect on the densities of adult mussels. But it also showed that the proportion of the tidal cycle for which a bed was exposed was a far more important variable. The densities of adult mussels tended to peak on beds with mean exposure times of between 30 and $40 \%$, with densities decreasing on higher and lower level beds. Because the upstream beds were generally low-lying, these exposure times were mainly found on the mussel beds in the lower reaches of the estuary. It was therefore their level on the shore, rather than their position at the mouth of the estuary, which explains why adult mussel densities were generally higher in the lower reaches of the estuary.

Nonetheless, the additional negative effect of distance up the estuary on adult density suggested that adult densities declined upstream over and above any effect of decreasing exposure time. However it is possible that the quadratic equation only imperfectly captured the effect of exposure time and that, as a result, the apparent influence of distance up the estuary was spurious. Further work is required to test this possibility.

As McGrorty et al. (1990) found for annual variations in spat fall over the estuary as a whole, the considerable spatial variations in spat density revealed by this study were related closely to the densities of adults on a bed. It seems that any spat failing to settle amongst the byssus threads of adults were quickly consumed by crabs. But the softness of the substratum had an additional, and highly significant, negative effect. This was probably because the adult byssus threads were covered in mud and thus inaccessible to spat, and some of those that did settle were subsequently smothered by further deposits of mud. Taking into account the effect of adult mussel density, spat densities were lower on the beds where the substratum was muddy, these generally occurring upstream and at the higher levels of the shore.

A number of the other variables had a small effect on mussel densities at particular ages. However, the dis- 
tance upshore, or exposure time, had the dominant effect over the entire life of the adult. Since spat only settled amongst adults, spat settlement was also closely related to exposure time. The conclusion of the study is that the main environmental gradient along which the population dynamics of mussels in the Exe estuary must be viewed is exposure time, and this will be investigated in a subsequent paper.

Acknowledgements. We thank Dr M. G. Morris for helpful comments on the manuscript and R. T. Clarke for statistical advice

\section{LITERATURE CITED}

Allen, D. M., Barker, D. L. (1990). Interannual variations in larval fish recruitment to estuarine epibenthic habitats. Mar. Ecol. Prog. Ser. 63: 113-125

Ambrose, W. G. (1986). Experimental analysis of densitydependent emigration of the amphipod Rhepoxynius abronius. Mar. Behav. Physiol. 12: 209-216

Baxter, J. M., Jones, A. M. (1989). The use of limpets in rockyshore surveillance and monitoring: an Orkney case-history. In: McManus, J., Elliot, M. (eds.) Developments in estuarine and coastal study techniques. Olsen and Olsen, Fredensborg, Denmark, p. 35-40

Bayne, B. L. (1965). Growth and delay of metamorphosis of the larvae of Mytilus edulis (L.). Ophelia 2: 1-47

Bayne, B. L., Salkeld, P. N., Worrall, C. M. (1983). Reproductive effort and value in different populations of the marine mussel, Mytilus edulis L. Oecologia 59: 18-26

Bayne, B. L., Worrall, C. M. (1980). Growth and production of mussels Mytilus edulis from two populations. Mar Ecol Prog. Ser. 3: 317-328

Beukema, J. J. (1982). Annual variation in reproductive success and biomass of the major macrozoobenthic species living in a tidal flat area of the Wadden Sea. Neth. J. Sea Res. 16: $37-45$

Bowman, R. S., Lewis, J. R. (1986). Geographical variation in the breeding cycles and recruitment of Patella spp. Hydrobiologia 142: 41-56

Bushek, D. (1988). Settlement as a major determinant of intertidal oyster and barnacle distributions along a horizontal gradient. J. exp. mar. Biol. Ecol. 122: 1-18

Connell, J. H. (1985). The consequences of variation in initial settlement vs. post-settlement mortality in rocky intertidal communities. J. exp. mar. Biol. Ecol. 93: 11-45

Dare, P. J. (1976). Settlement, growth and production of the mussel, Mytilus edulis L., in Morecambe Bay, England. Fishery Invest., Lond. (Ser 2) 28 (1): 1-25

Dayton, P. K. (1971). Competition, disturbance, and community organisation: the provision and subsequent utilisation of space in a rocky intertidal community. Ecol. Monogr. 41: 351-389

Essink, K., Bos, A. H. (1985). Growth of three bivalve molluscs transplanted along the axis of the Ems estuary. Neth. J. Sea Res. 19: 45-51

Eyster, L. S., Pechenik, J. A. (1987). Attachment of Mytilus edulis $\mathrm{L}$. larvae on algal and byssal filaments is enhanced by water agitation. J. exp. mar Biol. Ecol. 114: 99-110

Frechette, M., Bourget, E. (1985a). Energy flow between the pelagic and benthic zones: factors controlling particulate organic matter available to an intertidal mussel bed. Can. J. Fish. Aquat. Sci. 42: 1158-1165
Frechette, M., Bourget, E. (1985b). Food-limited growth of Mytilus edulis L. in relation to the benthic boundary layer. Can. J. Fish. Aquat. Sci. 42: 1166-1170

Griffiths, R. J. (1981). Population dynamics and growth of the bivalve Choromytilus meridionalis ( $\mathrm{Kr}$.) at different tidal levels. Estuar. coast. Shelf Sci. 12: 101-118

Hancock, D. A. (1973). The relationship between stock and recruitment in exploited invertebrates. Rapp. P.-v. Réun. Cons. int. Explor. Mer. 164: 113-131

Harvey, M., Vincent, B. (1989). Spatial and temporal variations of the reproduction cycle and energy allocation of the bivalve Macoma balthica (L.) on a tidal flat. J. exp. mar Biol, Ecol. 129: 199-217

Harvey, M. Vincent, B. (1990). Density, size distribution, energy allocation and seasonal variations in shell and soft tissue growth at two tidal levels of a Macoma balthica (L.) population. J. exp. mar. Biol. Ecol. 142: 151-168

Hassell, M. P., Southwood, T R. E., Reader, P. M. (1987). The dynamics of the Viburnam Whitefly (Aleurotrachelus jelinekii): a case study of population regulation. J. Anim. Ecol. 56: 283-300

Hastings, A., Wolin, C. L. (1989). Within-patch dynamics within a metapopulation. Ecology 70: 1261-1266

Hughes, T P. (1990). Recruitment limitation, mortality, and population regulation in open systems: a case study. Ecology 71: $12-20$

Hughes, R. N., Griffiths, C. L. (1988). Self-thinning in barnacles and mussels: the geometry of packing. Am. Nat. 132: $484-491$

Jackson, G. A. (1986). Interaction of physical and biological processes in the settlement of planktonic larvae. Bull. mar. Sci. 39: 202-212

Jones, R. E., Nealis, V. G., Ives, P. M., Scheermeyer, E. (1987). Seasonal and spatial variation in juvenile survival of the cabbage butterfly Pieris rapae: evidence for patchy density-dependence. J. Anim. Ecol. 56: 723-737

Kendall, M. A., Lewis, J. R. (1986). Temporal and spatial patterns in the recruitment of Gibbula umbilicalis. Hydrobiologia 142: 15-22

Lewis, J. R. (1964). The ecology of rocky shores. English Universities Press, London

Lewis, J. R. (1986). Latitudinal trends in reproduction, recruitment and population characteristics of some rocky littoral molluscs and cirripedes. Hydrobiologia 142: 1-13

Lewis, J. R., Bowman, R. S., Kendall, M. A., Williamson, P. (1982). Some geographical components in population dynamics: possibilities and realities in some littoral species. Neth. J. Sea Res, 16: 18-28

Lomnicki, A. (1978). Individual differences between animals and the natural regulation of their numbers. J. Anim. Ecol. 47: $461-475$

Lomnicki, A. (1980). Regulation of population density due to individual differences and patchy environment. Oikos 35 : 185-193

McGrorty, S., Clarke, R. T., Reading, C. J., Goss-Custard, J. D (1990). Population dynamics of the mussel Mytilus edulis: density changes and regulation of the population in the Exe estuary, Devon. Mar. Ecol. Prog. Ser. 67: 157-169

Menge, B. A., Farrell, T. M. (1989). Community structure and interaction webs in shallow marine hard-bottom communities: tests of an environmental stress model. Adv. ecol. Res. 19: 189-262

Morrisey, D. J. (1987). Effect of population density and presence of a population competitor on the growth rate of the mud snail Hydrobia ulvae (Pennant). J. exp. mar. Biol. Ecol. 108: 275-295

Murray, J. W (1980). The Foraminifera of the Exe estuary. In: 
Boaich, G. I (ed.) Essays on the Exe estuary. Devon Ass. Special No. 2, Devonshire Press, Torquay, p. 89-115

Okamura, B. (1986). Group living and the effects of spatial position in aggregations of Mytilus edulis. Oecologia 69: $341-347$

Peterson, C. H., Black, R. (1987). Resource depletion by active suspension feeders on tidal flats: influence of local density and tidal elevation. Limnol. Oceanogr. 32 (1): 143-166

Possingham, H. P., Roughgarden, J. (1990). Spatial population dynamics of a marine organism with a complex life cycle. Ecology 71: 973-985

Raimondi, P. T. (1990). Patterns, mechanisms, consequences of variability in settlement and recruitment of an intertidal barnacle. Ecol. Monogr. 60: 283-309

Remane, A., Schlieper, C. (1971). Biology of brackish water. Wiley-Interscience, New York

Roughgarden, J., Iwasa, Y (1986). Dynamics of a metapopulation with space-limited subpopulations. Theor Popul. Biol. 29: 235-261

Roughgarden, J., Iwasa, Y., Baxter, C. (1985). Demographic theory for an open marine population with space-limited recruitment. Ecology 66: 54-67

Scheltema, R. S. (1971). Larval dispersal as a means of genetic exchange between geographically separated populations of shallow water benthic marine gastropods. Biol. Bull. mar. biol. Lab., Woods Hole 140: 284-322

Seed, R. (1976). Ecology. In: Bayne, B. L. (ed.) Marine mussels Cambridge University Press, Cambridge, p. 13-66

Smaal, A. C., van Stralen, M. R. (1990). Average annual growth and condition of mussels as a function of food source. Hydrobiologia 195: 179-188

Smaal, A. C., Verhagen, J. H. G., Coosen, J., Haas, H. A.

This article was submitted to the editor
(1986). Interaction between seston quantity and quality and benthic suspension feeders in the Oosterschelde, the Netherlands. Ophelia 26: 385-399

Southwood, T. R. E., Hassell, M. P., Reader, P. M., Rogers, D. J. (1989). Population dynamics of the Viburnam Whitefly (Aleurotrachelus jelinekii). J. Anim. Ecol. 58: 921-942

Suchanek, T. H. (1985). Mussels and their role in structuring rocky shore communities. In: Moore, P. G., Seed, R. (eds.) The ecology of rocky coasts: essays presented to J. R. Lewis D. Sc. Hodder and Stoughton, London, p. 70-96

Sutherland, J. P. (1990). Recruitment regulates demographic variation in a tropical intertidal bamacle. Ecology 71 : 955-972

Taylor, A. D. (1990). Metapopulations, dispersal, and predator-prey dynamics: an overview. Ecology 71. 429-433

Vincent, B., Joly, D., Brassard, C. (1989). Effets de la densité sur la croissance du bivalve Macoma balthica (L.) en zone intertidale. J. exp. mar. Biol. Ecol. 126: 145-162

Watkinson, A. R. (1985). On the abundance of plants along an environmental gradient. J. Ecol. 73: 569-578

Widdows, J., Feith, P., Worrall, C. M. (1979). Relationships between seston, available food and feeding activity in the common mussel, Mytilus edulis. Mar. Biol. 50: 195-207

Wildish, D. J., Kristmanson, D. D. (1984). Importance to mussels of the benthic boundary layer. Can. J. Fish. Aquat. Sci. 41. $1618-1625$

Wilson, F. S. (1990). Temporal and spatial patterns of settlement: a fjeld study of molluscs in Bogue Sound, North Carolina. J. exp. mar Biol. Ecol. 139: 201-220

Witman, J. D., Suchanek, T H. (1984). Mussels in flow: drag and dislodgement by epizoans. Mar. Ecol. Prog. Ser. 16: $259-268$

Manuscript first received: December 17, 1990

Revised version accepted: May 2, 1991 